\title{
Influence of Phosphorus Microalloying on the Microstructure and Mechanical Properties of DA761 Superalloy
}

\author{
Zhuangqi $\mathrm{Hu}^{1}$, Wenru Sun ${ }^{1}$, Shulin Yang ${ }^{1}$, Shouren Guo ${ }^{1}$ and Hongcai Yang ${ }^{2}$ \\ ${ }^{1}$ Institute of Metal Research, Chinese Academy of Sciences, Shenyang 110016, P. R. China \\ ${ }^{2}$ Northeastern University, Shenyang 110004, P. R. China
}

\begin{abstract}
Effects of phosphorus microalloying on the microstructure and mechanical properties of direct-aging DA761 alloy have been studied. The aim of this work is to find a new way to develop a higher performance of wrought superalloy. The optimum addition of phosphorus in DA761 alloy is determined by investigating effects of phosphorus and boron on the microstructure and properties of DA761 alloy, that are compared to GH761 alloy treated by standard heat treatment. The stability of microstructure and properties of fine-grain DA761 alloy with optimum content of phosphorus is proved by studying the evolution of microstructure and properties of the alloy after long-term high temperature ageing. The practicability of phosphorus microalloying in improving the mechanical properties of DA761 alloy is verified by smelting a $500 \mathrm{~kg}$ ingot and detecting the microstructure and properties of billet near the size of engine disk. The results verify the phosphorus microalloying and fine-grain direct aging treatment in improving commercial GH761 alloy. Mechanism of phosphorus microalloying is also discussed. [doi:10.2320/matertrans.MF200908]
\end{abstract}

(Received December 1, 2008; Accepted May 1, 2009; Published June 25, 2009)

Keywords: phosphorus, GH761 alloy, fine-grain treatment, mechanical property

\section{Introduction}

Superalloys are vastly used in the aeronautical, astronautical, navigation, energy and transportation engineering, that are highly alloyed with about ten main alloying elements. Besides, some trace elements are also added to improve the mechanical properties.

Long time ago phosphorus is recognized as a deleterious trace element, which must be strictly controlled. ${ }^{1-3)}$ Recently, the study of phosphorus effect on some wrought superalloys made a big breakthrough, that it has a beneficial effect on the contrary. In 1993, the researchers in the Institute of Metal Research, Chinese Academy of Sciences first found that the stress-rupture life of commercial GH761 alloy at $650^{\circ} \mathrm{C}$ and $637 \mathrm{MPa}$ increased quickly if the phosphorus content rose up from 0.0005 mass $\%$ to 0.016 mass $\%$, and dropped down beyond the peak amount. ${ }^{4)}$ In 1994, Cao and Kennedy ${ }^{5)}$ found the same phosphorus effect on IN718 alloy, that the peak life at $649^{\circ} \mathrm{C}$ reached when the phosphorus content was 0.022 mass $\%$ or so.

Phosphorus seriously segregates to the grain boundary of superalloys, ${ }^{6}$ ) weakens the grain boundary cohesive force, ${ }^{7)}$ retards the diffusion along grain boundary and changes the phase precipitation. ${ }^{8)}$ Boron is also an important microalloying element in superalloys, that is prone to segregate on the grain boundary ${ }^{9)}$ and enhances the mechanical property if the boron amount is in an appropriate content. ${ }^{10)}$

Following the above mentioned summary, to study the mechanism of phosphorus modification in superalloys becomes one of the hot research fields, which are worth to understand deeply.

\section{Experiment Procedures}

GH761 master alloy rods with $140 \mathrm{~kg}$ have been smelted in a $200 \mathrm{~kg}$ vacuum induction furnace, which had a composition (mass\%) of Ni 44.27, Fe 32.65, Cr 13.06, W 3.15, Mo 1.66, Al 1.63, Ti 3.36, P 0.0007, B 0.005, C 0.046, Si 0.079, S
Table 1 P contents of GH761 alloy containing $0.005 \%$ B.

\begin{tabular}{ccccc}
\hline Alloy No & 1 & 2 & 3 & 4 \\
\hline $\mathrm{P} /$ mass\% & 0.0007 & 0.013 & 0.018 & 0.023 \\
\hline Alloy No & 5 & 6 & 7 & \\
\hline $\mathrm{P} /$ mass\% & 0.028 & 0.031 & 0.040 & \\
\hline
\end{tabular}

$0.003, \mathrm{Ce}<0.002$. Afterwards, the master alloy rods were cut into pieces with $10 \mathrm{~kg}$ each, which was remelted into ingots having various contents of phosphorus by adding Fe-P ferroalloy. The composition is listed in Table 1.

After $1120^{\circ} \mathrm{C} / 12 \mathrm{~h}$ homogenization treatment, the ingots were forged with three steps down to $30 \mathrm{~mm} \times 30 \mathrm{~mm}$ square bars. The beginning forging temperature was $1120^{\circ} \mathrm{C}$, and the end forging temperature was $950^{\circ} \mathrm{C}$. Finally the square bars were rolled to round rods with $16 \mathrm{~mm}$ in diameter. The standard heat treatment system of $\mathrm{GH} 761$ alloy was: $1120^{\circ} \mathrm{C} / 2 \mathrm{~h} \mathrm{WQ}+850^{\circ} \mathrm{C} / 4 \mathrm{~h} \mathrm{AC}+750^{\circ} \mathrm{C} / 24 \mathrm{~h}$ $\mathrm{AC}$. The fine-grain rods were obtained by direct aging treatment of $830^{\circ} \mathrm{C} / 4 \mathrm{~h} \mathrm{AC}+720^{\circ} \mathrm{C} / 24 \mathrm{~h} \mathrm{AC}$, that was named as DA761 alloy.

The tensile properties were tested both at room temperature and $650^{\circ} \mathrm{C}$, and the stress rupture property was tested at $650^{\circ} \mathrm{C}$ under a stress of $637 \mathrm{MPa}$.

The microstructure was characterized by optical microscope, scanning electron microscopies (S360 and JSM6301F) and transmission electron microscope (TECNAI 20).

\section{Results and Discussion}

\subsection{Effects of phosphorus}

Figure 1(a) is the grain structure, while Fig. 1(b) shows the $\gamma^{\prime}$ precipitation. When the $\mathrm{P}$ content is $0.0007 \%$, not much phase precipitation happens (Fig. 2(a)), when the P content reaches $0.023 \%$, the phase precipitation is enhanced and the phase particles are homogeneously and discretely distributed along the grain boundary (Fig. 2(b)); when the P content 


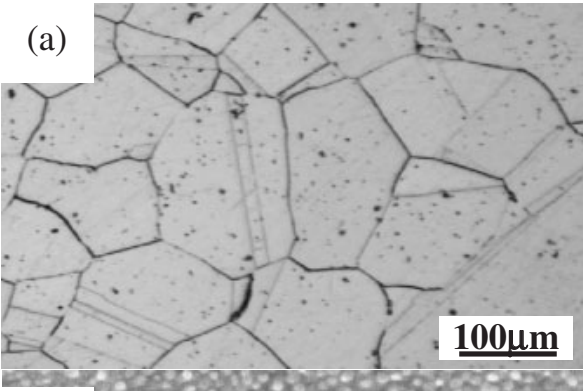

(b)

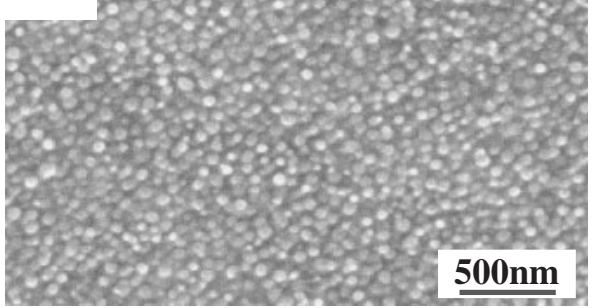

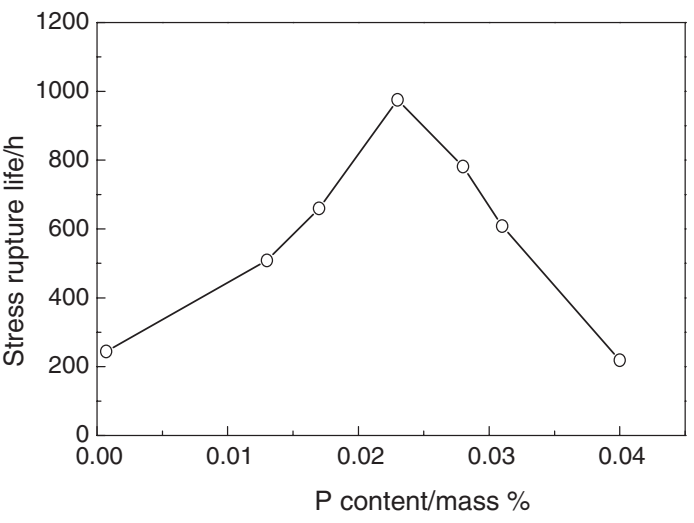

Fig. 3 Effect of phosphorus on the rupture life of $\mathrm{GH} 761$ alloy at $650^{\circ} \mathrm{C}$ and $637 \mathrm{MPa}$.

Fig. 1 Grain structure and $\gamma^{\prime}$ precipitation of GH761 alloy.

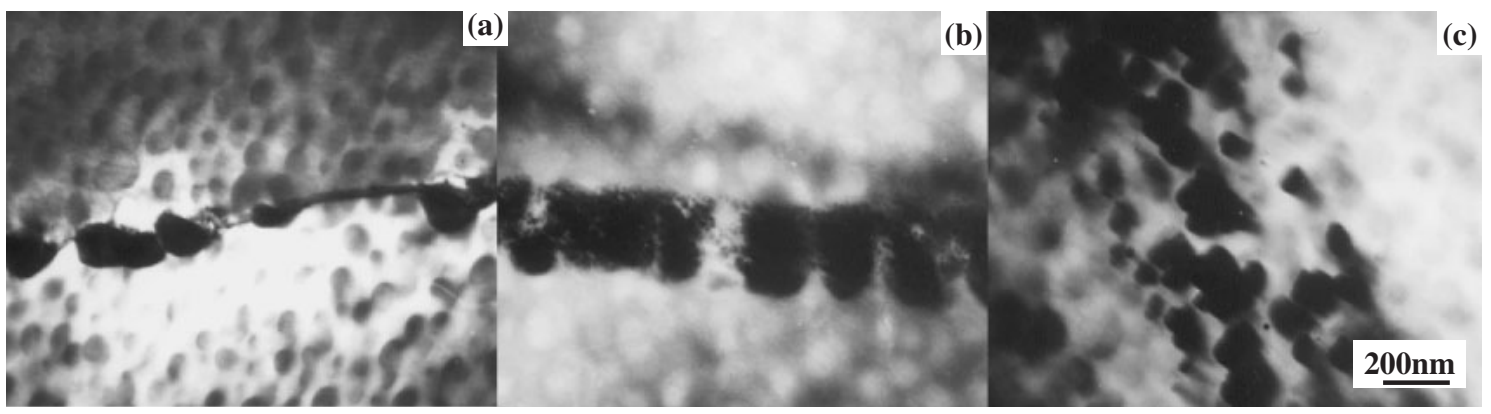

Fig. 2 Effect of phosphorus content on the grain boundary precipitation of GH761 alloy. (a) $0.0007 \% \mathrm{P}$ (b) $0.023 \% \mathrm{P}$ (c) $0.040 \% \mathrm{P}$

increases up to $0.040 \%$, the particles become too much and link together like a network (Fig. 2(c)).

Below $<0.04 \% \mathrm{P}$, there has no influence on the tensile properties (Fig. 3), but there has a peak stress-rupture life $\left(650^{\circ} \mathrm{C} / 637 \mathrm{MPa}\right)$ at $0.023 \% \mathrm{P}$, which is about $1000 \mathrm{~h}$ compared about $250 \mathrm{~h}$ of the GH761 alloy containing $0.0007 \% \mathrm{P}$. The effect of phosphorus on the intergranular fracture area of GH761 alloy stress ruptured at $650^{\circ} \mathrm{C}$ and $637 \mathrm{MPa}$, which is shown in Fig. 4(a). Figure 4(b) $(0.013 \% \mathrm{P})$ and Fig. $4(\mathrm{c})(0.023 \% \mathrm{P})$ show reasonable plastic deformation.

\subsection{Effects of direct aging}

Select No. 4 alloy with optimum phosphorus content $(0.023 \%)$ and boron content $(0.005 \%)$ to study the influence of primary direct aging temperature, that is 780, 800, 830, 850,870 and $950^{\circ} \mathrm{C}$ kept for $4 \mathrm{~h}, \mathrm{AC}$. The same secondary aging temperature was fixed at $720^{\circ} \mathrm{C} / 24 \mathrm{~h}, \mathrm{AC}$. The average grain size is about $40 \mu \mathrm{m}$ directly treated from 780 to $950^{\circ} \mathrm{C}$, but it is about $150 \mu \mathrm{m}$ when there has a solid solutioning treatment at $1120^{\circ} \mathrm{C}$ in the standard heat treatment of GH761 alloy. Figure 5 shows the effect of direct aging primary treatment temperature on the $\gamma^{\prime}$ phase precipitation in DA761 alloy. Below $870^{\circ} \mathrm{C}$, the $\gamma^{\prime}$ size does not change much. Figure 6 demonstrates the influence of primary direct aging treatment temperature on the tensile properties of DA761 alloy both at room temperature and $650^{\circ} \mathrm{C}$, while Fig. 7 shows the influence on stress-rupture property at $650^{\circ} \mathrm{C}$ and $690 \mathrm{MPa}$.

From Fig. 6 and Fig. 7, it can be decided that $830^{\circ} \mathrm{C}$ is an optimum primary direct aging treatment temperature which has better mechanical properties, both strength and ductility. For comparison, the stress rupture life of DA761 alloy treated with $830^{\circ} \mathrm{C}$ primary direct aging is $419 \mathrm{~h}$ tested at $650^{\circ} \mathrm{C}$ and $690 \mathrm{MPa}$, but that treated with standard heat treatment is only $245 \mathrm{~h}$ tested at $650^{\circ} \mathrm{C}$ and $637 \mathrm{MPa}$. Figure 8 shows the fracture morphologies of the alloy treated with different primary direct aging temperature, in which $800^{\circ} \mathrm{C}-830^{\circ} \mathrm{C}$ primary direct aging has better ductile fracture mode. Table 2 shows the tensile strength and ductility of DA761 alloy are also higher than those of GH761 alloy.

\subsection{Effect of large-size billet}

DA761 alloy was smelted in a $500 \mathrm{~kg}$ vacuum induction furnace and cast into an ingot having $460 \mathrm{~kg}$. Afterwards, it was remelted in a vacuum consumable electrode arc furnace into a round ingot with $250 \mathrm{~mm}$ in diameter, which has a chemical composition listed in Table 3.

After various steps of hot working, a billet with a dimension of $430 \mathrm{~mm}$ in diameter and $72 \mathrm{~mm}$ in thickness was produced. Figure 9 is the macrostructure of the billet. Table 4 and Table 5 are the mechanical properties of billet. It proves that the billet of GH761 alloy modified with 


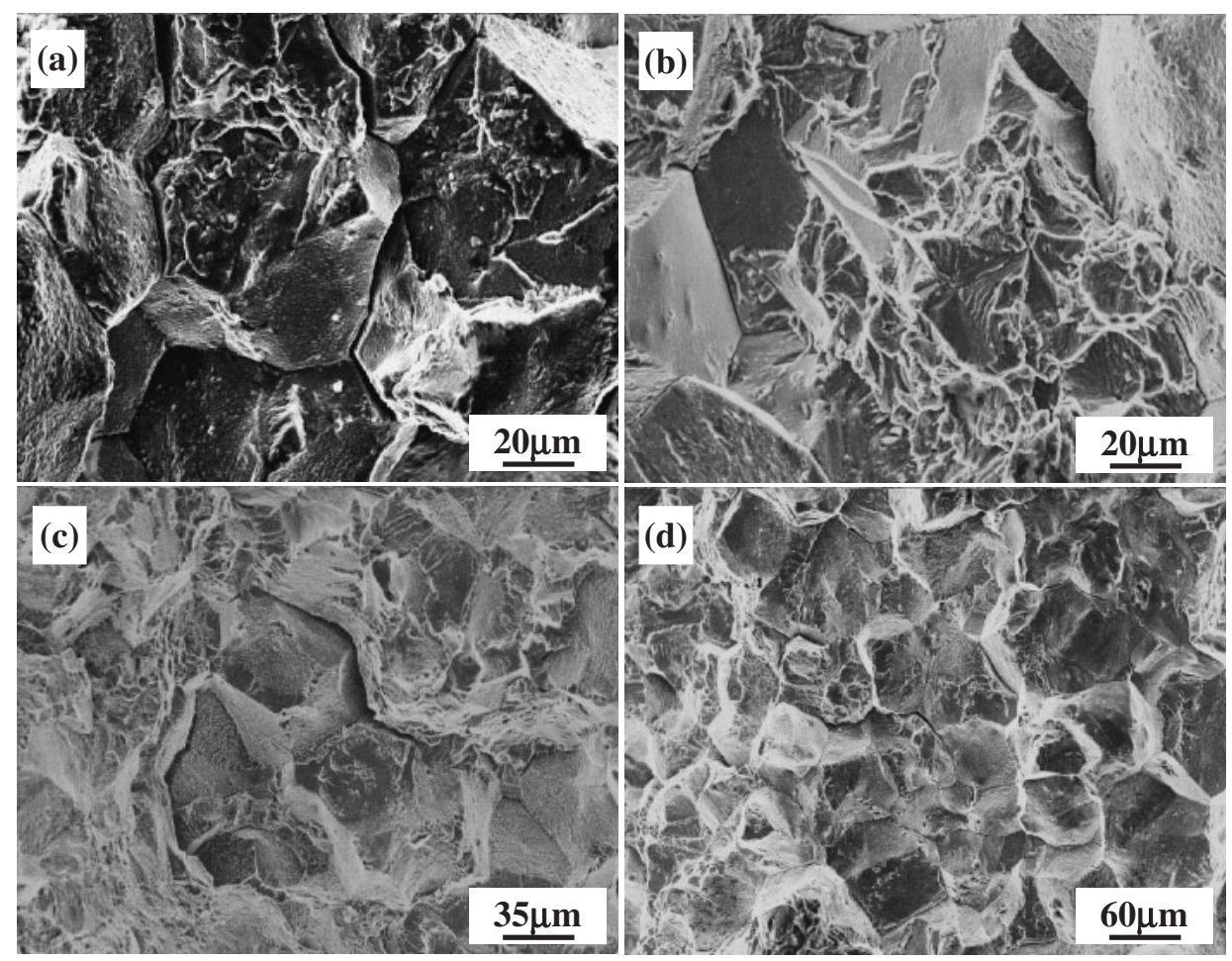

Fig. 4 Effect of phosphorus on the fracture surface of GH761 alloy stress ruptured at $650^{\circ} \mathrm{C}$ and $637 \mathrm{MPa}$ (a) $0.0007 \% \mathrm{P}$, (b) $0.013 \% \mathrm{P}$, (c) $0.023 \% \mathrm{P}$ and $(\mathrm{d}) 0.040 \% \mathrm{P}$.
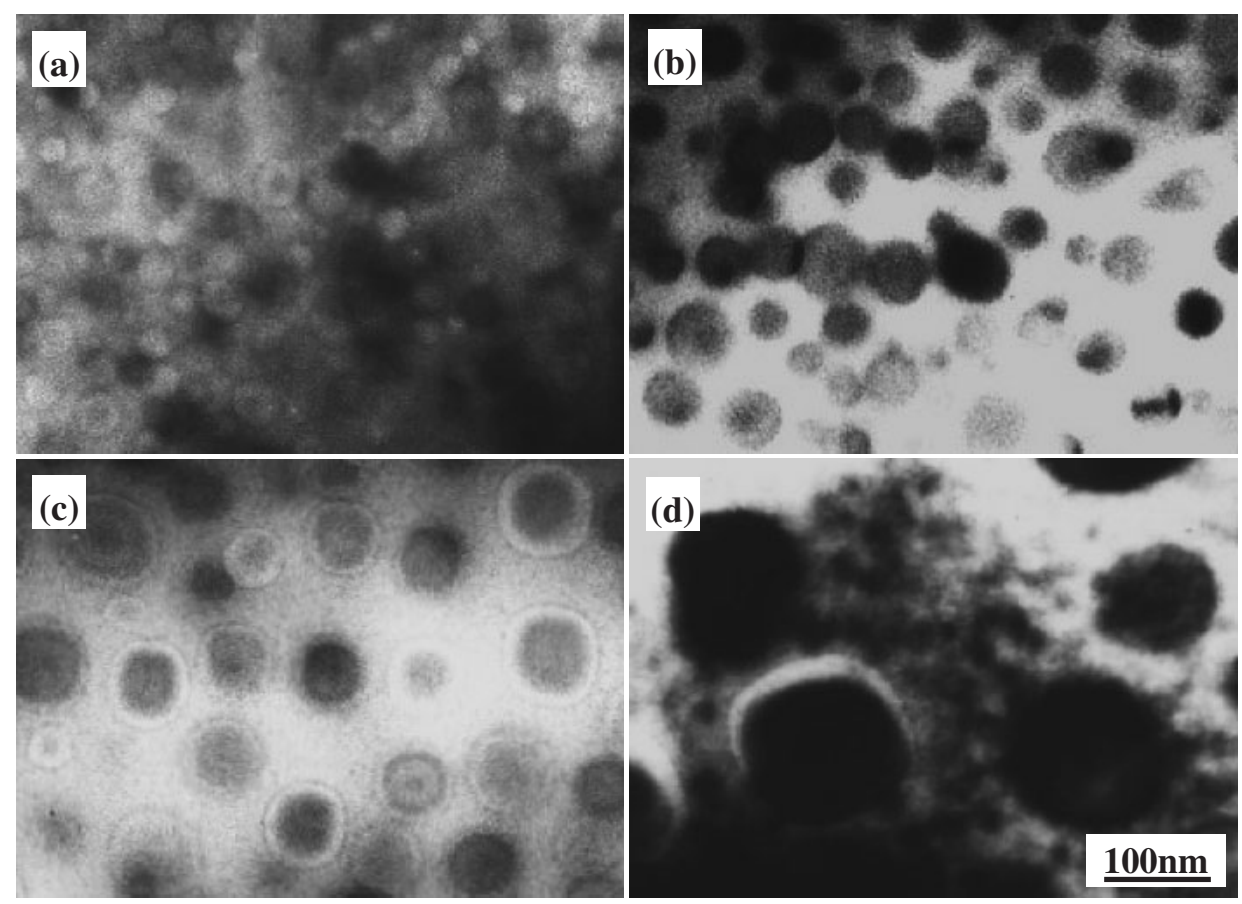

Fig. 5 Effect of primary aging temperature on the precipitation of $\gamma^{\prime}$ phase in DA761 alloy with $0.023 \% \mathrm{P}$ (a) $780^{\circ} \mathrm{C}$, (b) $830^{\circ} \mathrm{C}$, (c) $870^{\circ} \mathrm{C}$ and (d) $950^{\circ} \mathrm{C}$

phosphorus $0.022 \%$ still has an excellent mechanical property that is higher than the commercial GH761 alloy billet.

\section{Discussion}

GH761 alloy is a typical $\gamma^{\prime}$ strengthening alloy coupled with $\mathrm{M}_{23} \mathrm{C}_{6}$ and $\mathrm{M}_{3} \mathrm{~B}_{2}$ grain boundary strengthening.
Phosphorus enhances the $\mathrm{M}_{23} \mathrm{C}_{6}$ and $\mathrm{M}_{3} \mathrm{~B}_{2}$ precipitation along the grain boundary. If $\mathrm{P}$ content is too low (such as $0.0007 \%$ ), the amount of carbide and boride is not enough to strengthen the alloy. If P content is too high, (such as $0.04 \%$ ) there are too much carbide and boride in the grain boundary, linking together like a continuous network that impairs the stressrupture life. Therefore the optimum P content is $0.023 \%$ 

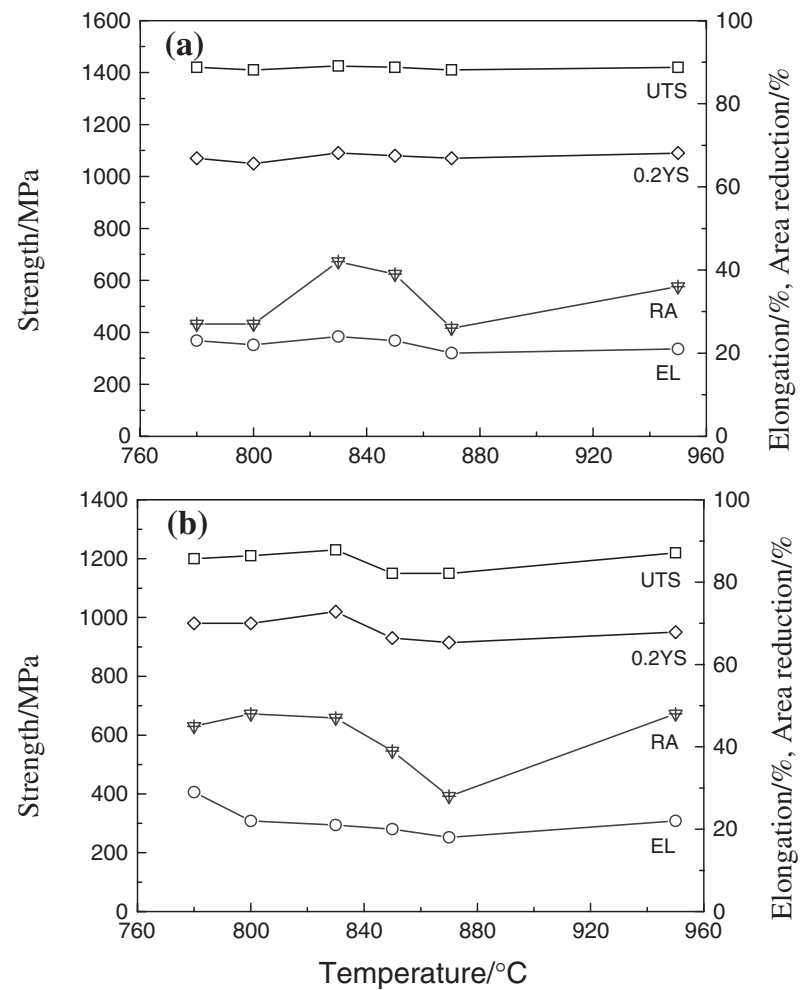

Fig. 6 Effect of primary direct aging temperature on the tensile properties of DA761 alloy with $0.023 \% \mathrm{P}$ at room temperature (a) and at $650^{\circ} \mathrm{C}$ (b).
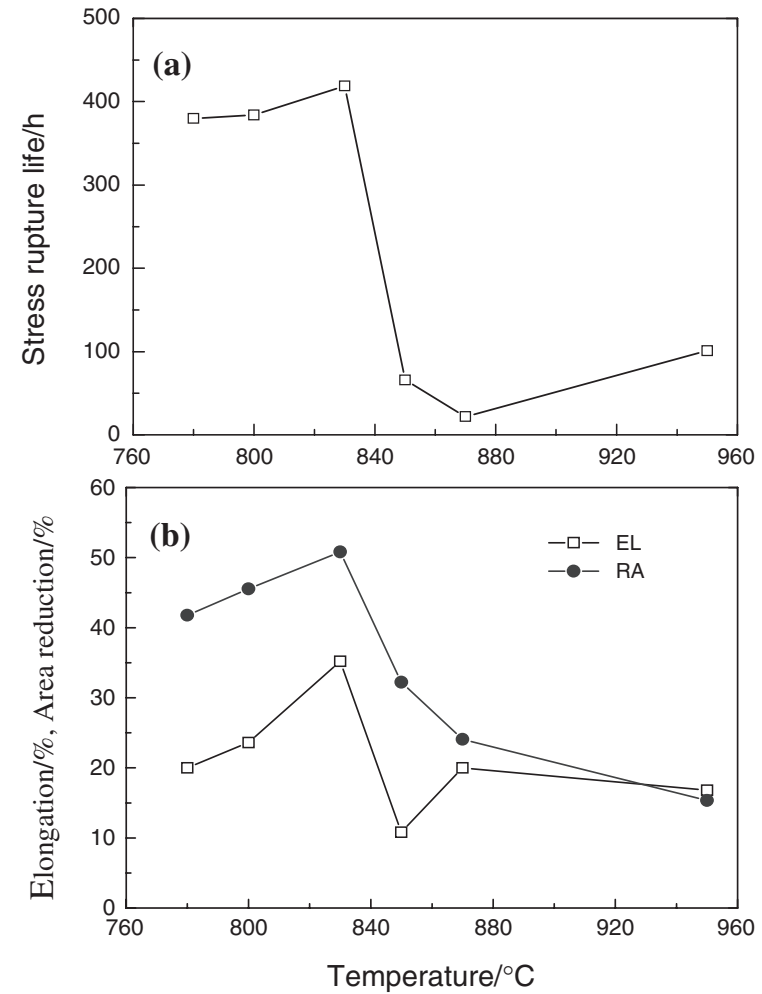

Fig. 7 Effect of primary direct aging temperature on the stress rupture properties of DA761 alloy with $0.023 \% \mathrm{P}$ at $650^{\circ} \mathrm{C}$ and $690 \mathrm{MPa}$ (a) stress rupture life (b) stress rupture ductility.
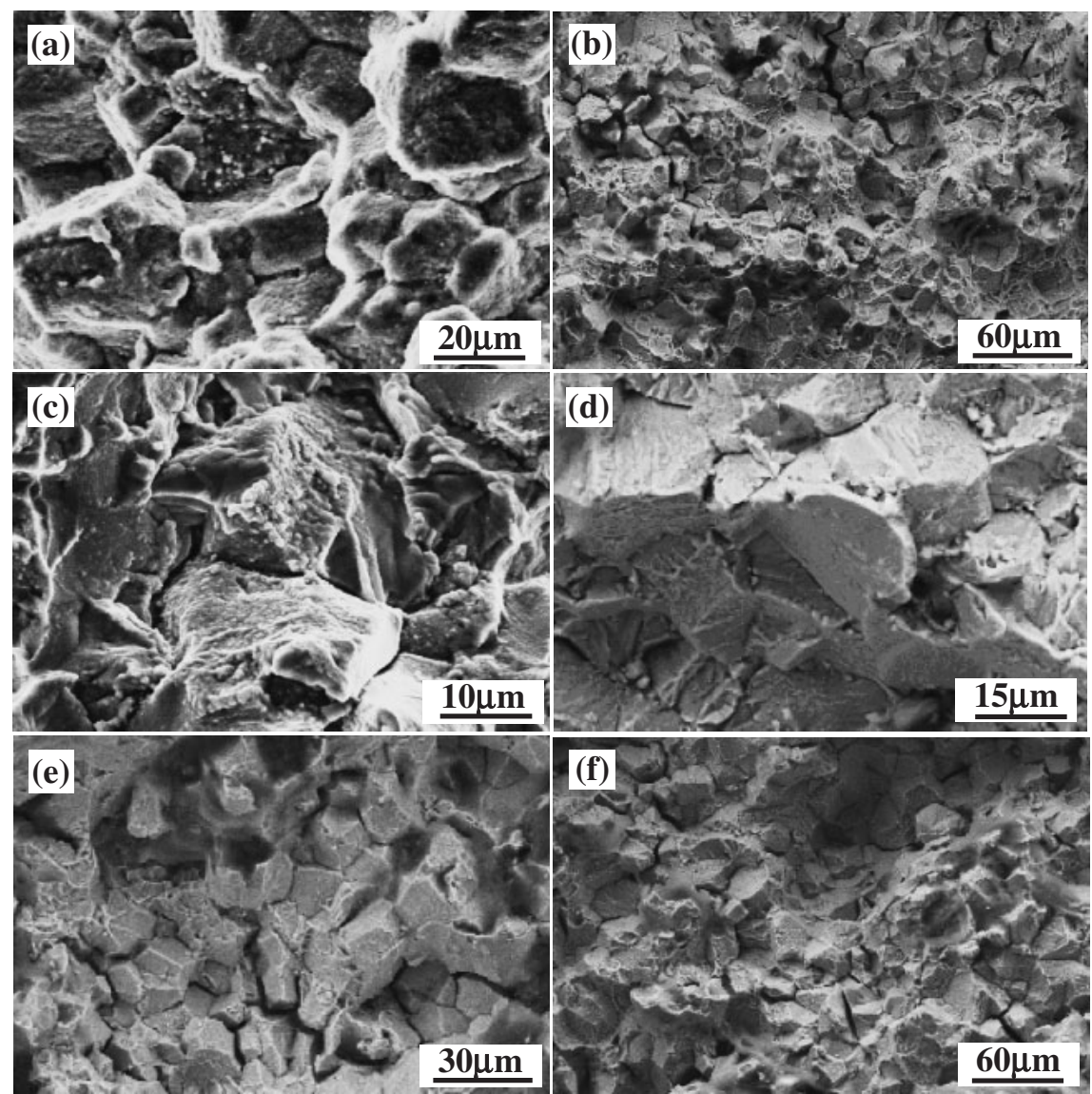

Fig. 8 Effect of primary direct aging temperature on the intergranular fracture surface of DA761 alloy with $0.023 \% \mathrm{P}$ stress ruptured at $650^{\circ} \mathrm{C}$ and $690 \mathrm{MPa}$, (a) $780^{\circ} \mathrm{C}$, (b) $800^{\circ} \mathrm{C}$, (c) $830^{\circ} \mathrm{C}$, (d) $850^{\circ} \mathrm{C}$, (e) $870^{\circ} \mathrm{C}$ and (f) $950^{\circ} \mathrm{C}$. 
Table 2 Tensile properties of GH761 alloy and DA761 alloy with $0.023 \%$ P.

\begin{tabular}{|c|c|c|c|c|c|c|}
\hline Alloy & Heat treatment & Test temperature $/{ }^{\circ} \mathrm{C}$ & $\mathrm{UTS} / \mathrm{MPa}$ & $0.2 \mathrm{YS} / \mathrm{MPa}$ & $\mathrm{EL} / \%$ & $\mathrm{RA} / \%$ \\
\hline \multirow{2}{*}{ GH761 } & $1120^{\circ} \mathrm{C} / 2 \mathrm{~h}, \mathrm{WQ}+850^{\circ} \mathrm{C}$ & Room temperature & 1320 & 930 & 19.5 & 24 \\
\hline & $/ 4 \mathrm{~h}, \mathrm{AC}+750^{\circ} \mathrm{C} / 24 \mathrm{~h}, \mathrm{AC}$ & 650 & 1160 & 890 & 16 & 24.5 \\
\hline DA761 & $+720^{\circ} \mathrm{C} / 24 \mathrm{~h}, \mathrm{AC}$ & 650 & 1230 & 1020 & 25 & 45 \\
\hline
\end{tabular}

Table 3 Chemical composition of DA761 alloy ingot (mass\%).

\begin{tabular}{|c|c|c|c|c|c|c|c|}
\hline Element & $\mathrm{Ni}$ & $\mathrm{Cr}$ & W & Mo & $\mathrm{Ti}$ & $\mathrm{Al}$ & $\mathrm{Fe}$ \\
\hline mass $\%$ & 42.70 & 12.63 & 2.87 & 1.66 & 3.26 & 1.60 & Balance \\
\hline Element & $\mathrm{P}$ & B & $\mathrm{C}$ & $\mathrm{Ce}$ & $\mathrm{Si}$ & $\mathrm{Mn}$ & S \\
\hline
\end{tabular}

Table 4 Comparison of tensile properties of billets.

\begin{tabular}{|c|c|c|c|c|c|}
\hline Heat treatment & Test temperature $/{ }^{\circ} \mathrm{C}$ & $\mathrm{UTS} / \mathrm{MPa}$ & $0.2 \mathrm{YS} / \mathrm{MPa}$ & $\mathrm{EL} / \%$ & $\mathrm{RA} / \%$ \\
\hline \multirow{2}{*}{ Bar by DA } & Room temperature & 1420 & 1090 & 22 & 42 \\
\hline & 650 & 1230 & 1020 & 25 & 45 \\
\hline \multirow{3}{*}{ Billet by DA } & Room temperature & 1360 & 1060 & 19 & 30 \\
\hline & 650 & 1200 & 1000 & 24 & 40 \\
\hline & 700 & 1110 & 950 & 18 & 30 \\
\hline treatment & 650 & 1160 & 890 & 16 & 24.5 \\
\hline \multirow{3}{*}{$\begin{array}{l}\text { Billet by standard } \\
\text { treatment }\end{array}$} & Room temperature & 1330 & 1024 & 15 & 21 \\
\hline & 650 & 1189 & 980 & 11 & 17 \\
\hline & 700 & 1083 & 927 & 13 & 21 \\
\hline
\end{tabular}

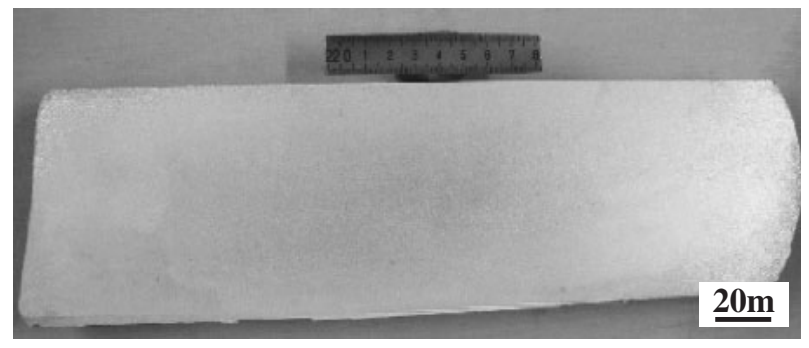

Fig. 9 Macrostructure of the billet.

or so. It means there exists a competition between the beneficial effect and deleterious effect of P modification. ${ }^{11)}$

Phosphorus is prone to segregate at the grain boundary, obstructing the movement of other alloying elements along the grain boundary. Phosphorus is also prone to move to the dislocations to impede the dislocation movement, playing a strong pinning effect, that can strengthen the alloy. For example, phosphorus can improve the anti-oxidation property due to the obstruction of oxygen penetration along grain boundary. ${ }^{12)}$

After heat treatment, phosphorus increases the grain boundary precipitation, such as $\mathrm{M}_{23} \mathrm{C}_{6}$ and $\mathrm{M}_{3} \mathrm{~B}_{2}$, phosphorus is insoluble in $\mathrm{MC}$ but dissolves in $\mathrm{M}_{23} \mathrm{C}_{6}$ and $\mathrm{M}_{3} \mathrm{~B}_{2}$. Too high phosphorus addition results in the excessive precipitation at grain boundary, while too low phosphorus content leads to many precipitate-free grain boundary. When the phosphorus content is adequate, the alloy exhibits an optimum morphology of the intergranular precipitation.
Table 5 Stress rupture properties of billets.

\begin{tabular}{cccc}
\hline Heat treatment & $\begin{array}{c}\text { Temperature } \\
/{ }^{\circ} \mathrm{C}\end{array}$ & $\begin{array}{c}\text { Stress } \\
/ \mathrm{MPa}\end{array}$ & $\begin{array}{c}\text { Life } \\
/ \mathrm{h}\end{array}$ \\
\hline Bar by DA & 650 & 690 & 419 \\
\hline Billet by DA & 650 & 690 & 249 \\
\hline Bar by standard treatment & 650 & 637 & 975 \\
\hline Billet by standard treatment & 650 & 588 & 448 \\
\hline
\end{tabular}

The most striking effect of phosphorus is that it greatly improves the stress-rupture property. When the phosphorus content is at the optimum level, the rupture life of GH761 alloy or DA761 alloy is the longest, about four times more than that of the alloy with the lowest phosphorus content, because it inhibits grain boundary sliding and selective oxidation. The special function of phosphorus is attributed to its effects on three factors: optimum grain boundary precipitation, obstruction of grain boundary oxidation and retardation of the creep rate.

Phosphorus has no noticeable influence on the weakly diffusion-controlled properties, such as tensile property, impact energy and fatigue crack growth rate at room temperature, but significantly modifies the strongly diffusion-dependent properties, such as stress-rupture and creep properties. Song ${ }^{13)}$ reported that increasing phosphorus content from 0.003 to $0.026 \%$ induces an increase of the creep activation energy for grain boundary sliding from 276.1 to $349.8 \mathrm{~kJ} / \mathrm{mol}$. 
Phosphorus tends to move to the residual liquid during the solidification due to the very low partition coefficient of phosphorus and the extremely low solubility of phosphorus in $\gamma$ matrix. The high concentration of phosphorus in the residual liquid delays the solidification rate of the alloy by a diffusion-controlled mechanism and finally enlarges the interdendritic area. If the concentration of phosphorus exceeds some limit, the harmful phosphide phase maybe precipitate out.

The basic mechanism of phosphorus in GH761 alloy and DA761 alloy can be summarized as follows: phosphorus segregates to grain boundary to obstruct the grain boundary diffusion in appropriate phosphorus content, and reduces grain boundary cohesion for excessive phosphorus content. Inhibition of grain boundary diffusion and reduction of grain boundary cohesion are two contradictory factors in the basic effects of phosphorus. It is the balance between these two main factors that determines whether the effect of phosphorus on stress-rupture property is beneficial or not.

The mechanism of grain size effect on tensile strength and ductility is much clear than phosphorus effect. According to Hall-Petch equation, the smaller the grain size, the higher the hardness and strength. If the grain size is $40 \mu \mathrm{m}$, the ultimate tensile strength, yield strength, elongation and area reduction at room temperature is $1420 \mathrm{MPa}, 1090 \mathrm{MPa}, 22 \%$ and $42 \%$ respectively, but it is $1320 \mathrm{MPa}, 930 \mathrm{MPa}, 19.5 \%$ and $24 \%$ respectively when the grain size is $150 \mu \mathrm{m}$. Same results are obtained when the tensile tests are done at $650^{\circ} \mathrm{C}$, that is, $1230 \mathrm{MPa}, 1020 \mathrm{MPa}, 25 \%$, and $45 \%$, respectively for $40 \mu \mathrm{m}$ grain size specimen, compared to $1160 \mathrm{MPa}, 890 \mathrm{MPa}, 16 \%$ and $24.5 \%$ for $150 \mu \mathrm{m}$ grain size ones.

\section{Conclusion}

(1) Phosphorus within the range of $0.0007-0.04 \%$ has no obvious influence on the tensile properties both at room temperature and $650^{\circ} \mathrm{C}$, but it extraordinarily lengthens the stress-rupture life tested at $650^{\circ} \mathrm{C}$. The best $\mathrm{P}$ content is about $0.023 \%$.

(2) Direct aging can produce fine-grained DA761 alloy containing $0.023 \% \mathrm{P}$. The optimum direct aging treatment is $830^{\circ} \mathrm{C} / 4 \mathrm{~h} \mathrm{AC}+720^{\circ} \mathrm{C} / 24 \mathrm{~h} \mathrm{AC}$, which has better tensile strength and ductility, both at room temperature and $650^{\circ} \mathrm{C}$, as well as better stress-rupture life at $650^{\circ} \mathrm{C}$ and $690 \mathrm{MPa}$, if compared to commercial GH761 alloy with standard heat treatment.

(3) After expanding the heat scale up to roughly half ton and producing the billet near the real size; the billet also has improved better mechanical properties than the billet having $0.0007 \% \mathrm{P}$ and heat treated without grain refinement.

\section{REFERENCES}

1) R. T. Holt and W. Wallace: Int. Met. Rev. 21 (1976) 1-24.

2) G. W. Meethan: Met. Technol. 11 (1984) 414-418.

3) M. McLean and A. Strang: Met. Technol. 11 (1984) 454-464.

4) W. Sun: Doctor dissertation, Institute of Metal Research, Chinese Academy of Sciences, (1993)

5) W. D. Cao and R. L. Kennedy: Superalloys 718, 625, 706 and Various Derivatives, ed. E. A. Loria, Warrendale, PA: TMS, (1994) 463-477.

6) R. G. Thompson, M. C. Koopman and B. H. King: Superalloys 718, 625, 706 and Various Derivatives, ed. E. A. Loria, Warrendale, PA: TMS, (1991) 53-70.

7) M. P. Seah: Acta Metall. 28 (1980) 955-962.

8) W. Sun, S. Guo, J. Guo, D. Lu and Z. Hu: Acta Metall. Sin. 31 (1995) 346-350 (in Chinese)

9) W. Chen, M. C. Chaturvedi, N. L. Richards and G. McMahon: Metall. Mater. Trans A 29A (1998) 1947-1954.

10) W. D. Cao and R. L. Kennedy: Superalloys 1996, ed. R. D. Kissinger, D. J. Deye, D. L. Anton, A. D. Cetel, M. V. Nathal, T. M. Pollock, D. A. Woodford, Warrendale, PA: TMS, (1996) 589-598.

11) Handbook of Chinese Aeronautical Materials: Vol. 2, Superalloys, 2nd ed. (China Standard Publishing House, 2002) 155-168.

12) W. R. Sun, S. R. Guo and Z. Q. Hu: Mater. Sci. Eng. A 247 (1998) 173-179.

13) H. Song: Doctor dissertation, Institute of Metal Research, Chinese Academy of Sciences, (1999). 